Preprint version from Cyprien Tasset : "Identifying as a precarious knowledge worker in France. Ambivalences and variations", Sociologia del lavoro - Special Issue I/2017, pp. 151-167.

Preprint version from: Cyprien Tasset: "Identifying as a precarious knowledge worker in France. Ambivalences and variations", in Sociologia del lavoro - Special Issue I/2017, "Il lavoro delle relazioni. Commitment e processi di soggettivazione nel free work", (Emiliana Armano, Marco Briziarelli, Federico Chicchi, Elisabetta Risi (eds.)), pp. 151-167.

https://www.francoangeli.it/riviste/Scheda_Rivista.aspx?IDArticolo=58754\&Tipo=Articolo\%20PDF \&lingua $=$ it\&idRivista $=83$

DOI: 10.3280/SL2017-145009

Cyprien TASSET

Chercheur associé au Laboratoire de Changement Social et Politique (Paris 7 Denis Diderot) Membre d'Origens Media Lab.

Abstract:

The creative precariat is the target of representations, elaborated by social scientists or other authors. Yet, little attention is dedicated to subjective appropriations of critical discourses on cultural work and precariousness. The author investigates this question in the Paris metropolis. Over the years 2008-2011, he conducted more than fifty interviews in Paris with individuals who carried artistic or intellectual activities and did not benefit from the backing of a steady employment contract. Interviews were focused on their working-lives, and on their conceptions regarding collective entities to which they could belong. Among these, a minority referred to a category popularized a few years before by an essay: the «intellos précaires ». The article shows how these precarious cultural workers invest the category, but also distanciate themselves from it and from the kind of precarity politics it contains.

Keywords:

Precariat; knowledge work; identification.

\title{
Identifying as a precarious knowledge worker in France. Ambivalences and variations
}

Surveying fifteen years of literature on work in culture and new media, Greig de Peuter (2014) aptly synthetized the social entity that it recurrently evoked as the «creative precariat ». De Peuter's point was that cultural workers on non-standard employment were not only « capitalism's preferred labour profile », that it to say a laboratory of neoliberalized work (p. 264), but that they could also be «a 
Preprint version from Cyprien Tasset : "Identifying as a precarious knowledge worker in France. Ambivalences and variations", Sociologia del lavoro - Special Issue I/2017, pp. 151-167.

strategic locus of resistance against » precarization (p. 265).

The first point is well represented in areas of anglophone sociology that are close to radical thinking. The particular vulnerability of «mental labour » to exploitation was highlighted as early as 2000, by Andrew Ross, taking a critical distance from enchanted discourses on the «new economy » (Ross, 2000), and it has often been verified since (Huws, 2010; Turrini and Chicchi, 2013). This topic has recently been reformulated into the concept of "passionnate work», the analysis of which is expected to «renew critical sociology» (Ballatore, del Rio Carral and Murgia, 2014, p. $3^{1}$ ). By unveiling the «passion trap », sociology might help individuals to reclaim some power on their lives. But such analyses could also contribute to sharpening the contradictions inherent to «free labor » (Terranova, 2000), or even be the basis for the constitution of collectives advocating the cause of precarized cultural and knowledge workers, which leads from the study of a new exploited workforce to the appreciation, or even to the stimulation, of its potential for resistance.

The subversive potential of immaterial labourers experiencing precarious postfordist employment relations was highlighted by postoperaist thinkers (Hardt \& Negri, 2000). Franco Berardi, for example, vehemently insisted on the crucial role of the « cognitariat» as the only collective subject able to shake the domination of «semiocapitalism» (Berardi, 2009, p. 9) ${ }^{2}$. Such theoretical developments had an impact on social movements. For example, research on Euromayday showed how sophisticated neo-marxist theories on cognitive capitalism and affective labour were transformed by activists into imagery, mottos and parades (De Sario, 2007; Mattoni, 2008). Creative workers organizations in the United Kingdom (Precarious Workers Brigade and Carrot Workers Collective, 2014) illustrate, to a lesser degree, the same sort of circulation between academic critical thought and social movements. Various endeavours by researchers to contribute to the formation of social movements include the research and intervention group Cultural Workers Organize in Canada (de Peuter, Cohen and Brophy), or the proposal of an insubordinated subjectivity for intermittent precarious workers, as «quinto stato » (Allegri, 2014).

Yet, little attention is dedicated to subjective appropriations of critical discourses on cultural work and precariousness. Are they appropriated outside universities and activist ranks, by social actors trying to make sense of their situation and to characterise their social identity? If so, whom are they used by? And how? Precarity is an ambiguous notion, loaded with strong, albeit confused, connotations of injustice. Thus, how are the various notions of the creative precariat integrated or rejected by actors whose sense of justice have been shaped by different trajectories and who belong to different areas of the field of cultural labour?

We have had the opportunity to investigate this question in the Paris metropolis. In France, the lexical nexus of precarity, (la précarité, les précaires, précariser, le précariat), has been present in the public debate on work and employment, if only irregularly, since the end of the 1970s, and it bears several meanings (Cingolani, 2005). In the beginning of the 2000s, précarité was a notion widely associated to poverty, but also to experimental rejuvenations of union activism, in sectors like fast-food restauration (Perrin, 2004), and to the movement of the «intermittents du spectacle » who

1 All references to texts originally in French, including our interviews, are translated in English by ourselves.

2 There is also a much more pessimistic side in Berardi's oscillations on this topic. See for example After the Future, especially chap. 4 (Berardi, 2011). 
Preprint version from Cyprien Tasset : "Identifying as a precarious knowledge worker in France. Ambivalences and variations", Sociologia del lavoro - Special Issue I/2017, pp. 151-167.

claimed they were part of the «précaires » (Corsani et Lazzarato, 2008).

In the landscape of discourses on precarity in France at the beginning of the $21^{\text {st }}$ century, one text is very close to considerations on the creative precariat. It is an essay, published in 2001 by Anne and Marine Rambach, a couple of novelists, publishers, and gay rights activists. Titled «Les intellos précaires » (approximatively: the precarious knowledge workers), it endeavoured to describe the condition of this new social group, in which the authors included themselves, among precarious «museum guides, teachers of French to foreigners, librarians, editors, secondary school teachers, publishers, writers, journalists, researchers, translators, photographers, editors » (Rambach \& Rambach, 2001, p. 36-37). Based on thirty interviews, their essay described the common lot of the «intellos précaires »: their adaptations to live with low incomes, the contrast between their passionate relationship to their work and their rejection of the corporate as well as civil service work. The authors highlighted the exciting and fulfilling activities of the intellos précaires as well as their exploitation by their employers. For example, a chapter is called: «Exploitation in the cultural sector» (p. 223). To explain the low «price of intellectual work» (p. 254), they pointed to the « symbolic reward system whose role is to alleviate and disguise the lack of pay and actual status » (p. 276), in a reasoning that echoes critical developments on cultural work as an avant-garde of conformity to capitalism's new demands.

The reception of Les Intellos précaires by French sociology was mixed. In the next decade, dozens of sociologists refered to the new social entity, but some criticized it for blurring differences between professions and poles of the creative industries (Tasset, 2011, p. 3-5). The book's emphasis on humour might also have stirred social scientists' distrust. Nevertheless, the press gave it a very favourable reception (Tasset, 2011, p. 9-11), maybe because journalists easily recognized in it their younger colleagues, often assigned to the «pigiste» (freelance) status (Chupin, 2014). Thus, this proposition for a new class (Barbrook, 2006) reached an audience far beyond academic specialists, and sounded familiar even to some that hadn't directly heard from the book. How far was it diffused? How did it impact on the way social actors perceived themselves, shaped their subjectivity, and « found their way in social space » (Boltanski and Thevenot, 1983)?

Over the years 2008-2011, during our doctoral research, we conducted more than fifty semistructured interviews in Paris with individuals who carried artistic or intellectual activities and did not benefit from the backing of a steady employment contract. Using the "snowball sampling" method, we diversified the profiles among interviewees belonging to the sectors of cultural production, expertise, academic and social work. Most of them had never experienced stable employment relationship, and worked under a variety of statutes, possibly several at once: autoentreprise, freelancing, CDD, portage, author. Their insurance - brittle - came from the networks of relationships they had established over the years, from their diplomas, and from the projects in which they had already proven themselves. We conducted the interviews so as to get an understanding of their working lives, and of their economic balance. One of the main questions of the inquiry was whether people related to proposals of collective identity (such as the «intellos précaires »), and if so, which and how.

This is the point on which we will focus in this article. It will take the form of a double and contradictory movement: first of expressions of identification to the «intellos précaires », then of 
Preprint version from Cyprien Tasset : "Identifying as a precarious knowledge worker in France. Ambivalences and variations", Sociologia del lavoro - Special Issue I/2017, pp. 151-167.

distanciation from them as, detailing the moral dimensions of their work experiences our interviewees deployed a complex relation to that social figure.

\section{1/ Subjectivating as an intello précaire}

\section{The contrasted social area of precarious knowledge work}

The social area covered by our inquiry is wide and heterogenous, but its heterogeneity offers an intelligible structure. The sharpest contrast is based on the level of professional integration. This integration culminated in people with linear trajectories, that is to say who had followed a specific training for their activity, had not exercised a different trade, but could develop a pluriactivity inside a well defined sphere of competence (eg: a musician who teaches the instrument he is a specialist of). Their professional identity was unambiguous. The incomes of those most integrated knowledge workers were rather regular and well above the minimum wage. Professionnal integration often went with family integration: a steady couple, with children. At the opposite pole, less integrated interviewees had experienced educational as well as professional bifurcations; the consistence between their training and their activities was weaker. Their activities tended to be scattered between fragmented areas and levels of qualification, and they experienced frequent and/or long intervals of full unemployment. Their professional identity was more indeterminate. Their income might sometimes reach high levels, but wasn't regular. Although they could be well over thirty, they were most often single and without children.

Some of our interviewees (especially at the most integrated pole) were little inclined to discuss their situation in terms of "precarity», and only a minority spontaneously evoked the «intellos précaires » as a category that made sense to describe them. This minority was closer to the least integrated pole, but it wasn't concentrated at its extremity, and it also reflected the various tendancies of the intermediate space between the poles of maximal and minimal professional integration. Indeed, a second principle of polarisation opposed on the one side precarious wage earners, turned towards public service or non governmental organisations, and on the other side independent or private sector workers.

It was also possible to distinguish several types of trajectories: graduates in the process of a more or less laborious insertion (wether towards a creative professionalism, or towards a stable waged position) - or, on the contrary, struggling to maintain a certain indetermination; middle-aged workers, weakened by personal accidents, fragilised by the precarious formats imposed by an employer in a dominant position, or exposed to tensions affecting their whole professional area. Cultural conversions after years and sometimes decades in an other career constitute a third type of trajectory, in which the person often benefits from resources external to his/her new activity, such as a spouse in regular employment, the property of the housing, or an ancient professional network offering the opportunity of an intermittent side-job.

These types of trajectories combine with the polarities relative to the degrees of professional 
Preprint version from Cyprien Tasset : "Identifying as a precarious knowledge worker in France. Ambivalences and variations", Sociologia del lavoro - Special Issue I/2017, pp. 151-167.

integration and to the sector and statutes to produce the heterogeneity of livelihoods that we observed. Therefore, self-categorised « intellos précaires » belong to a contrasted social space which they do not epitomize. We are not focusing on them because they are particularly representative of precarious knowledge workers, but because of their subjective relation to a collective representation of such workers.

\section{Working lives of self-declared intellos précaires}

Who were those of our interviewees who spontaneously mentioned the «intellos précaires » as a social figure they identified themselves to? We are going to portrait some of them, insisting on their trajectories, professional situations and subjective relation to work.

Delphine, 39, is a freelance journalist working mainly for the internal bulletin of a big firm, and parttime as a bilingual receptionist. Coming from «a rather bourgeois » family with a father working in marketing, she studied to work in luxury advertisment, began a career of short term contracts in various firms, excited by the job but cautious not to get entangled in work relations she progressively perceived as « very violent». Nevertheless, after a decade of activity, her superior in a prestigious institution where she had a temporary employment dismissed her in strongly conflictual circumstances and she came back to live for a while with her parents, at more than thirty, bitter and wishing to reorient. Seizing an opportunity offered by one of her ancient employers, she began freelancing on a regular basis for them, writing on a technical topic she was familiar with. While she had comfortably earned her life before, she now approximatively earns the minimum wage, even with the help of a few missions in communication, obtained through ancient colleagues. Yet, that is enough to live in the Paris apartment she had bought in the early 2000s with the savings from ther first decade of activity and the help of her parents. She has no children, consumes less than she used to, and declares she enjoys this sobriety. Most of all, she appreciates working from home, far from office crowding and hierarchical authority:

«For me it was super important not to be in a relationship of subordination; I've realized it while talking with a friend who told me not to forget that an employment contract included a subordination clause. I had never thought about it and suddenly that explained many things in my career. [As a freelance journalist, she offers] services or in the case articles, and the editorial chief decides wether to say yes or no, but there is no relationship of authority or subordination, and so I think it's great ».

Jenny, 34, has been teaching in adult education in auto-entreprise for a few years, and is also very involved in a series of artistic and media projects. From a family of very politicized left-wing teachers, Jenny studied literature, philosophy and theater. At 23, as she just failed an exam that would have made her a waged student in a prestigious theater arts class, she decided to « earn at least half her living, to have the luxury of leisure » and to carry on her literary and artistic vocation outside of the more professionalized paths. Since then, her income came from disparate sources: mostly tutoring in the early years, then writing popularization books, freelancing in the cultural press, a short but 
Preprint version from Cyprien Tasset : "Identifying as a precarious knowledge worker in France. Ambivalences and variations", Sociologia del lavoro - Special Issue I/2017, pp. 151-167.

lucrative mission for an NGO, and later participation in «market research », a «righ-wing job », which she took following the example of another person who used it as an extra job leaving free time for «literary passion». These activities have always been accompanied by occasional income from her artistic projects, such as writing grants. Jenny also lived on social aid for a while. She thus got « used to live for cheap »: «I consummed very little. No clothes, I was not buying discs and then I kept this habit, I bought a few books but mostly I borrowed them from libraries and sometimes I stole them. Or I rescued books from friends who emptied their library (...). And I did not travel ». This « frugal » life changed, a few years before the interview: « Now I work as a trainer in written and oral communication (...) I began on temporary contracts (...). It is becoming regular, and I can count on it. Then I took an auto-entrepreneur status; I charge 560 euros for a day ». Well paid and easily planifiable, this job allows Jenny to « self-subsidize » time for her artistic activities. Besides, around the same time, Jenny's parents donated her a small apartment near Belleville. Jenny still says she is precarious, but «this is precariousness with an apartment and money ».

A graduate from the most prestigious French business school but attracted to literature, Laurent, 38, worked a few months for a large industrial group, and drew from this experience « a hatred for the corporate world, it seemed completely artificial, I couldn't resign, at 23, to conform myself to the role of the executive ». For several years, he makes a living by intermittently transcripting conferences and meetings for big companies, while dedicating his free time to literary explorations which resulted in the publication of books in a trendy and gay publishing house. Yet they weren't sufficiently sucessful to make Laurent a full-time writer. A friend introduced him to communication and advertising agencies, and he progressively became, in his late twenties, a freelance « corporate journalist ». His income is irregular: «In the last two mounths, I made only 840 euros, while in October, I was the king, I earned 3200 euros in three days ». That is enough to pay the rent of his appartment in the neighbourhood of Belleville, where he lives alone. His activity is divided into several professional fields: «I define myself as a writer, as a translator, as a journalist, as a copywriter» resulting in several legal statuses: «I am auto-entrepreneur, sometimes I'm an employee, at the moment I translate a book so I am paid in royalties, and when I work for France Culture I am registered as an intermittent $»$.

Other self-categorized "intellos précaires » have less complex professional identities, and can therefore be evoked more concisely. Mirabelle is a pigiste (freelance journalist) of 34 , graduated from a renowned school. She shares a worspace with other pigistes, and considers this is a precious solidarity. She is specialized in writing articles about work, but frustrated that the editors don't let her use a critical tone. Desiring to work less and to enjoy more free time, she is sliding towards communication, which she finds ethically barely worse thant journalism, more remunerative and less stressful. Charlotte, 41, studied literature in University, but didn't achieve her $\mathrm{PhD}$ and turned towards edition, unsucessfuly for a while, then better after a training as proofreader financed by social aid. From then, she was «not rich, but not poor anymore », thanks to a «system » where unemployment benefits played an important part: « as I did several short term contracts, I have been registered as unemployed, and still now, on the mounthes when I am working, I get nothing, but the mounths when I don't work, my benefits are still available». Thus, she adds, "I am functionning somehow as an intermittent du spectacle». 
Preprint version from Cyprien Tasset : "Identifying as a precarious knowledge worker in France. Ambivalences and variations", Sociologia del lavoro - Special Issue I/2017, pp. 151-167.

\section{A category linked to a sense of (un)justice}

In Les Intellos précaires, Anne and Marine Rambach intended to render visible an «invisible group ». It seems to have partly worked, as during their investigation, the people they interviewed often expressed an « unexpected happiness (...) to be named » when they told the the title of the book they were preparing (Rambach \& Rambach, 2001, p. 25-26). The reactions of those among our interviewees who had read the Rambachs' essay reflected this joy. Laurent seemed proud to assert, as early as the email answearing our request for an interview, that he was « exactly what Anne and Marine Rambach once called an intello précaire». When Delphine discovered the book through a former companion form her communication school, who asserted she belonged to that category, she found it «extremely enjoyable » and «totally recognized [her]self in some descriptions ». Charlotte «already knew we lived this same insecurity, this is not the book that made me think that we lived more or less the same thing », but it confirmed and named her sense of a common precarious condition. She too was recognized as an intello précaire before recognizing herself as such: «I knew someone who worked at [a big publishing house] who immediately thought of me, lent me the book, and I read it right away» and « really recognized» herself. Jenny enjoyed it because it broke her impression that she was alone in her case. Mirabelle « adored $»$ Les Intellos précaires, recognized her friends as well as herself, and was very marked by it.

Being able to put a name on their social condition was not only an epistemic pleasure for our interviewees. It was also a relief from the discomfort of perceiving themselves as singular aberrations. Now a collective matter, precarity among knowledge workers became a matter of justice, and not only individual mistakes and failures. An alienation was alleviated. For Jenny, discovering that one is «not alone in this shit» leads to the awareness that, as an author of scenarios, she was treated unfairly: «there is a devaluation of writing (...). Image is well paid. Realization is relatively well paid. The scenario is not well paid. It's incredible ». Reading Les Intellos précaires enabled her to acquire "the this is not normal» that is to say, the consciousness of an injured interest. Mirabelle's attachment to this book is immediately linked to a denunciation, which she found in it, of the precarisation of the French press. What Charlotte most recognized in the essay of the Rambachs are the administrative absurdities surrounding her work. For example, should she declare her periods of work before being paid (usually mounths later) and risk blocking her unemployment benefits, or not declare them, which is a fraud? «This is absurd! », she exclaims. Even Delphine, although her managerial culture seems more remote from social critique, declares that she «totally agrees with the principles » of resistance against precarisation proposed by the Rambachs « and I apply them since I am a journalist ». Indeed, she sued her main employer, demanding to be integrated on an open-ended contract.

Thus, we see that recognizing oneself as an intello précaire is inseparable from the subjective adhesion to a protest against a situation perceived both as collective and as unjust. As is often the case, the assertion of a new social entity is indissociable from a claim for justice (Boltanski, 1982). Indeed, the Rambachs exhorted their readers to extend the collective consciousness stirred by their book into actions such as the setting up of a «Précaires Pride» (Rambach \& Rambach, 2001, p. 304), or the creation of organizations advocating for a more adapted social protection and 
Preprint version from Cyprien Tasset : "Identifying as a precarious knowledge worker in France. Ambivalences and variations", Sociologia del lavoro - Special Issue I/2017, pp. 151-167.

denouncing the most abusive employers. Besides, arguing that «the more you accept precarious situations, the more you precarise the others », they urged readers to actively vindicate their rights as professionals, and proposed a «charter of the precarious » such as «discuss the prices », «always demand a contract», know your rights (Rambach \& Rambach, 2001, p. 306-310). As we see, the social figure of the intello précaire carries a specific precarity politics, quite similar to the perspective of a professional union.

\section{2/ The misunderstanding between creative precariat subjectivities and precarity politics}

\section{The unsteadiness of social critique}

The arguments deployed in Les Intellos précaires are not absolutely original. The two words accolated in the title are associated to specific historical moments. Intellos is a slang diminutive of intellectuels. The use of this term in the Rambachs' essay can be traced back to its first uses at the dawn of the $20^{\text {th }}$ century. According to historian Christophe Charle, it was often charged with «a claim for justice for those who played the game of classical professional careers and expected their work to be decently rewarded»(Charle, 1990, p. 64). This message, recognizable in Les Intellos précaires is indisputably a matter of "social critique», which, developed with the working class movement in the $19^{\text {th }}$ century, asked for action against poverty and against the destruction of existing solidarities (Boltanski \& Chiapello, 1999, p. 82-84). The adjective précaire belongs to a more recent episode from the history of social critique. It entered the lexicon of French labour politics in the late 1970s to express a denounciation, by union activists, of degraded forms of employment that were used to shatter workers' unity, and to increase the level of exploitation of weaker workers. But the essay by the Rambach couple also contained vivid reminiscences of the writings from the Parisian literary bohemia of the mid $19^{\text {th }}$ century (Seigel, 1986; Tasset, 2010), which Boltanski and Chiapello considered as the laboratory of the «artist critique », focused on capitalism as a factor of inauthenticity and oppression of individual faculties (Boltanski \& Chiapello, 1999, p. 82-84).

The category of intellos précaires is thus linked to various critical trends, which might be a source of tension among its users. As we have seen, the strong association between the affirmation of precarious knowledge workers as a new social entity, and social critique, is an appeal of Les Intellos précaires in the eyes of some of our interviewees. Yet, the combination between the perspective of the social critique and the focalisation on the creative precariat is unsteady, as shown by Mirabelle's relativisation of her own woes. This journalist's interest for the intellos précaires is taken in the more general frame of a concern for economic inequalities and poverty. In this perspective, her own « precariousness » case is «not very serious »: «You can find it's unfair that having studied for six years [after the A level], having gratuated from the best journalism school in France, I laboriously earn 1500 euros a month, with steep irregularities and overdrafts all the time, and that my comfort depends on my boyfriend. But it's not very serious ». A sympathizer of left wing journals such as 
Preprint version from Cyprien Tasset : "Identifying as a precarious knowledge worker in France. Ambivalences and variations", Sociologia del lavoro - Special Issue I/2017, pp. 151-167.

l'Humanité (where she would love to work) and Fakir, Mirabelle notices that the toughness of the «capitalist enterprise » isn't limited to the creative precariat; « it unfortunately affects a very large proportion of employees in France and worldwide». Therefore, she is far from considering her own situation as the most serious injustice she's aware of.

Thus, it is from the same perspective of social critique, denouncing selfishness and unequalities, that she invests and rejects, or at least strongly relativizes, the cause of the intellos précaires. Social critique seems at the same time a necessary as well as an unsteady basis for a collective identity of precarious knowledge workers.

\section{Assuming one's choice versus the possibility of critique}

This unsteadyness is particularly apparent when interviewees insist that their situation is the pleasurable result of their free and still reversible choice. Charlotte approaches from this case when she praises Anne and Marine Rambach for the «honesty » and «humour » that allowed them not to paint the intellos précaires as mere victims. She adds: «many are not only victims, they also have chosen this condition $»$. She includes herself in the lot:

«we aren't workers on an assembly line; lots of people could pass an exam if they wanted and enter the administration, anything, to do something else. Lots of people I know. As for myself, if I couldn't stand it anymore, I could apply for a junior high school teacher position, or in the administration. (...) in my opinion, there would be a way out of this precarity. If I am very honest ».

What risks being lost on the way of such honesty is the possibility of voicing claims, that is to say of the social critique. This is more clear in the case of Delphine. She is very conscious of her bad employment conditions and unfavorable earnings, and admits it affects her: "There are times, particularly in December when I receive my final paychecks, I have great moments of loneliness (...)». Yet, she insists on the pleasurable aspects of her work patterns. While her permanent colleagues have to commute every day and are packed in a small offices, she has the freedom to write her papers «in pyjamas » when she wants. Besides, as we have seen earlier, she doesn't feel subordinated in her work. She also vehemently insists on the « intellectual satisfactions » she derives from her «exhilarating job »: «I have access to a vision, a total freedom, a form of happiness »; «Every morning, I wake up full of enthusiasm about what's ahead of me». She compares her «thrilling » work experience to the Rambachs':

«How enjoyable it is to do what you love when you chose it! That is the heart of the matter. And they [the Rambachs] say it in their book. We chose these activities. We aren't there by chance. Why are they struggling to keep their publishing house afloat and writing books? Because it makes them thrill I guess ». 
Preprint version from Cyprien Tasset : "Identifying as a precarious knowledge worker in France. Ambivalences and variations", Sociologia del lavoro - Special Issue I/2017, pp. 151-167.

From Delphine's point of view, this powerful experience of pleasure balances her poor economic condition. The latter is the inevitable price to pay for the former; she «made a choice » and consents, as an «adult » to the necessary consequences of the link between the attractiveness of a creative activity and elementary economic mechanisms of «supply and demand »: "This is also why I don't complain. I chose this job. There are too many of us, it's a great job, obviously there is more supply than demand, it inevitably drives prices down, the editorial leaders can afford to not be very fair with some freelancers because they know there are ten others waiting ». Coping with the drawbacks of her condition as a freelance is the only «adult » attitude. Delphine speaks as if, when she turned towards journalism a few years before, she responsibly took an option in transparent circumstances.

This notion of a responsible choice is central to Delphine's facework during the interview. It neutralizes at the same time the suspicion that she could be less happy than she pretends, and the possibilites of any critical expression regarding her present condition. Following this conception, social order is not negociable in terms of justice or unjustice; it is so robust that it is only a matter of individual choices. Therefore, the sense of a collective injustice is implicitely reduced to a childish disposition, a despicable lack of firmness. There are no unfair situations, only inadapted individuals, and fully adhering to a category based on social critique would make Delphine one of them. This is not definitely Delphine's position, but certainly one pole in the internal tensions of her discourse, and it points to an incompatibility between the subjective inclusion in a collective entity tinged with a sense of injustice, and a certain sense of one's individuality, favoured by the neoliberal work regime. Here, a work experience based on pleasure and on emotional involvment « reverses itself into alienation » (Cingolani, 2014, p. 67).

\section{Competing identifications}

An other dimension of the experiences of the creative precariat that might oppose to identifying as an intello précaire consists in the relation to creative work itself. Our interviews suggest a distinction between two cases: one based on the identification as an artist, and the other on the exploratory side of creative work.

Laurent's case is the former. Although the biggest part of his income results from his freelance copywriter activity, he cultivates ambiguity regarding his professional identity and his status, and uses the adjective «precarious » to blur other potential identifications. He recently shifted his copywriter activity from waged labour to auto-entreprise, but is not willing to consider himself as an « indépendant» (self-employed): «I don't say I have clients, that's horrible. (...) because these words bear very strong social realities, and therfore, one sometimes doesn't want to assume ». He is as uneasy with his job as with his status of self-employed. For example, while his parents appreciate to know what profession they can attribute to him, he refuses to identify to his main activity: «I am not a copywriter » and reasserts his polyactivity: «I have no fixed job ».

Hence a real difficulty: Laurent has «always had trouble defining [him]self by an activity». He « hates » the question: «what do you do? » To which he « doesn't know the answer ». A plausible solution could be the term of «author», which fits with one of his legal statutes, and partially 
Preprint version from Cyprien Tasset : "Identifying as a precarious knowledge worker in France. Ambivalences and variations", Sociologia del lavoro - Special Issue I/2017, pp. 151-167.

matches with his writing work for advertising agencies: «I can say I am an author, the term is wide enough, and its neutral and sober ». But «author» is at the same time too abstract, and too close to the role of a writer, to which Laurent doesn't firmly pretend.

This is where «precarity » appears as a means to alleviating the weight of social determination contained in his role of independent copywriter: «If I had to label myself, I'd use précaire rather than self-employed ». The term allows him to reverse the fragility of his artistic pretentions into a refined disquiet, artistic feeling par excellence, but to which he thinks that artists, taken in a strict dichotomy between success and failure, do not have access: " an artist will never see himself as precarious; he is beyond that: whether he is failed, or star-crossed, or he is a hit ».

However, the teerm "précarité » is not immediately available for the meaning Laurent intends to give it. He has to hollow it out of its « economic connotations » of poverty or social struggle, and to insist on his « existential precariousness », a « relational fragility » set in his «personal nature ». In other words, he has to purify it from any traces of social critique, and to invest it with significations belonging to the ideal of the artist critique. He can then present himself as above the "poor », yet neither an « artist », nor a professional copywriter: a « bourgeois-bohème », as he says, but without the irony in which the creator of that category had mocked its pretentions to authenticity (Brooks, 2000). Laurent's symbolic bricolage is based on an appropriation of the term "précarité », but he shifts its meaning and turns away from the social critique encapsulated in the category of «intellos précaires».

A different path away from social critique is Jenny's. Despite her enthusiasm about the category of intellos précaires, she is puzzled by the question of what it means to her, and evokes instead another identification: «I am in trouble explaining how I consider this group. It's artists or intellectuals that have difficulty earning their lives; what matters is to go on with one's work, inventing new things, creating in the margins. Power to the margins! ». Whereas the Rambachs' essay was focused on the economic condition of the creative precariat, the perspective of the "margins » is more about endurance and recognition outside the most institutionnal spaces. Indeed, as she is able to "selfsubsidize " and as the absence of rent alleviates her financial preoccupations, Jenny's main concern is about the use of her free time, her creative self-discipline, and her ability to gain recognition for her creativity. She is looking for «that space inside me that allows me to produce » and her «vertigo » is due to her indecision about «where to invest [her] energy». Therefore, her main problem doesn't lie in the confrontation with an employer, but in an intimate negociation with her own desires and fears. She is more invested in this internal struggle than in conflicts that could arise on the theme of « precarity».

Among the historical sources of the Rambachs' essay, Jenny's experience is more bohemian, with a strong uncertainty about the value of her products, than intellectual, in the sense of definite professions demanding a fair level of earnings ${ }^{3}$. Her intense dedication to her creative activities also illustrates a more general tendancy: for the better educated fractions of younger generations, accustomed to autonomous activity by longer stays in higher education and finding inherited identities less and less meaningful, creative work tends to appear as a means to exploring and

3 Such a reinterpretation of professions as arenas for recognition more than as a means for making a living, is also analysed by Turrini and Chicchi (2013, p. 514-515). 
Preprint version from Cyprien Tasset : "Identifying as a precarious knowledge worker in France. Ambivalences and variations", Sociologia del lavoro - Special Issue I/2017, pp. 151-167.

asserting their own individual identity (Cingolani, 2014, p. 42-43; Mc Robbie, 2016, p. 22). This exploratory character of the activity, centered on the self, relegates in the background the issue of exploitation. Thus, it diverts from a politics of precarity invitating for collective action on the basis of labour interests - unless such a politics could tackle this dimension, adequately theorized as the « capital/individuality contradiction » (Corcuff, 2006).

\section{Conclusion}

Precarious cultural and knowledge workers with fragmented professional identities, the interviewees we quoted here had heard about the category of «intellos précaires » and they felt concerned by it. Yet, their relations to this pole of collective identification oriented towards social critique were highly ambivalent. A moment of strong identification to the social figure described by the Rambachs was often balanced by a moment of distanciation. This distanciation took several forms: in some cases, social critique proved a volatile basis for a collective identity of still relatively privileged precarious creative workers; in other cases, the argument of choice locked the very possibility of critique; and sometimes, the interviewees built up symbolic bricolages that were meant to fit more closely with their experiences of creative work. If collective protests are to emerge out of the creative precariat, their political composition will have to take into account the complexities of its subjectivities.

\section{References}

Allegri G (2014). L'insubordination au travail du « Cinquième État». Enoncés collectifs et invention institutionnelle. In : Contarini S and Marsi L (eds.) Précariat. Pour une critique de la société de précarité. Nanterre : Presses Universitaires du Grand Ouest.

Ballatore M., del Rio Carral M. and Murgia A. (2014) Présentation. Quand passion et précarité se rencontrent dans les métiers du savoir, Recherches sociologiques et anthropologiques, $\mathrm{n}^{\circ}$ 45-2, p. 1-13. DOI : $10.4000 /$ rsa. 1240 .

Barbrook R (2006) The Class of the New. London: Skyscraper publishing.

Berardi F (2009) Precarious Rhapsody, Semiocapitalism and the pathologies of the post-alpha generation. London : Minor Compositions.

Berardi F (2011) After the Future. Chico: AK Press.

Boltanski L (1982) Les Cadres. Paris: Minuit.

Boltanski L. and Thevenot L. (1983) Finding one's Way in Social Space: A Study Based on Games. Information sur les Sciences Sociales, 22/4-5. DOI: 10.1177/053901883022004003.

Boltanski L. and Chiapello E. (1999) Le nouvel Esprit du Capitalisme. Paris: Gallimard.

Brooks D (2000) Les Bobos. Paris: Florent Massot. 
Preprint version from Cyprien Tasset : "Identifying as a precarious knowledge worker in France. Ambivalences and variations", Sociologia del lavoro - Special Issue I/2017, pp. 151-167.

Charle C (1990) Naissance des «intellectuels », 1880-1900. Paris: Minuit.

Chupin I (2014) Précariser les diplômés? Les jeunes journalistes entre contraintes de l'emploi et ajustements tactiques, Recherches sociologiques et anthropologiques, 45-2. DOI: 10.4000/rsa.1282.

Cingolani P (2005) La Précarité. Paris : PUF.

Cingolani P (2014) Révolutions précaires. Essai sur l'avenir de l'émancipation. Paris: La Découverte.

Corcuff P (2006) Individualité et contradictions du néo-capitalisme, SociologieS http://sociologies.revues.org/462 [no DOI].

Corsani A. and Lazzarato M. (2008) Intermittents et Précaires. Paris : Amsterdam.

De Peuter G (2014) Beyond the Model Worker: Surveying a Creative Precariat. Culture Unbound: Journal of Current Cultural Research, 6, 263-284. DOI: 10.3384/cu.2000.1525.146263.

De Peuter G. Cohen N. and Brophy E. (2012) Interns Unite! (You Have Nothing to Lose-Literally). Briarpatch Magazine, 9 [no DOI].

De Sario B (2007) "Precari su Marte": An Experiment in Activism against Precarity. Feminist Review, 87, 21-39. DOI: 10.1057/palgrave.fr.9400374.

Hardt M. and Negri A. (2000) Empire. Harvard: Harvard University Press.

Huws U (2010) Expression and expropriation : the dialectics of autonomy and control in creative labour. Ephemera. Theory and Politics in Organization, 10/34. 504-521 [no DOI].

Mattoni A (2008) Serpica Naro and the Others. The Media Sociali Experience in Italian Struggles Against Precarity, PORTAL Journal of Multidisciplinary International Studies, 52, 1-24. DOI : 10.5130/portal.v5i2.706.

Mc Robbie A (2016) Be Creative: Making a Living in the New Culture Industries. London, John Wiley \& Sons.

Perrin E (2004) Chômeurs et précaires au cœur de la question sociale. Paris: La Dispute.

Precarious Workers Brigade and Carrot Workers Collective (2014). Free Labour Syndrome. Volunteer Work and Unpaid Overtime in the Creative and Cultural Sector. In: Kozlowski M. Kurant A., and Sowa J. (eds.), Joy Forever: The Political Economy of Social Creativity. London: MayFlyBooks/Ephemera.

Rambach A. and Rambach M. (2001) Les intellos précaires. Paris: Fayard.

Ross A (2000) The Mental Labor Problem, Social Text, 18, 1-31. DOI: 10.1215/01642472-18-2_63-1.

Seigel J (1986) Bohemian Paris: Culture, Politics, and the Boundaries of Bourgeois Life, 1830-1930. Baltimore and London: John Hopkins University Press.

Tasset C (2010) «Construction d'enquête et définition des groupes sociaux », SociologieS [En ligne], consulté le 24 novembre 2016. URL: http://sociologies.revues.org/3214 [no DOI].

Tasset C (2011) «Entre sciences sociales, journalisme et manifestes. La représentation de groupes sociaux réputés émergents dans la france des années 2000 », Les Enjeux de l'Information et de la Communication, $\mathrm{n}^{\circ} 12 / 3$, Supplément, pp. 139-157 [no DOI].

Terranova T (2000) «Free Labor: Producing Culture for the Digital Economy ». Social Text. 18/33-58. DOI: $10.1215 / 01642472-18-2 \_63-33$.

Turrini M. and Chicchi F. (2013) « Precarious subjectivities are not for sale: the loss of the measurability of labour for performing arts workers », Global Discourse, 3:3-4, 507-521,

DOI: 10.1080/23269995.2014.885167. 